CHERYL CLAASSEN

\section{Washboards, Pigtoes, and Muckets: Historic Musseling in the Mississippi Watershed-Introduction}

Mussels gleaned from the rivers of the Mississippi watershed have supported two important industries and provided millions of dollars of income to land-based and river-based men and women since the $1860 \mathrm{~s}$. This volume is a book about the historic uses of freshwater bivalves from rivers of the Mississippi watershed, for pearls and buttons.

Collecting freshwater pearls was the impetus for harvesting shellfish from 1860 to 1900 with the revenue for a single pearl often being in the thousands of dollars. Pearl rushes on a river created a boom-town-like atmosphere and attracted local, as well as out-of-state, musselers and buyers. Proceeds from pearls brought to many individuals instant fortune and have a heretofore unacknowledged role in the capitalization of rural America in the period prior to 1930 . Pearl revenue exceeded that of all other natural product industries combined, excepting timber, in many areas.

Most important of the commercial uses of riverine shellfish was the production of buttons from 1891 until approximately 1950 . It is this industry that is the focus of this monograph. Shell buttons were made of both pearly ocean and freshwater shell for centuries in Europe before being manufactured in the Northeast United States beginning in the 1850s. The United States product, based on an imported material, had a hard time competing with the European product, and the industry was dying out in 1890 . John Boepple, an immigrant master button turner, redirected the United States industry in 1891 when he began producing pearl buttons in Muscatine, Iowa, using shells from the Mississippi River. Ocean pearl button machinery was soon adapted to the harder freshwater shells, and dozens of plants opened in Muscatine. At first, the shells were procured from the Mississippi River bordering Iowa, but by 1910 , they were coming from as far away as Alabama and eastern Kentucky. The activity on dozens of rivers and in dozens of manufacturing plants and blank cutting shops is annotated, complemented by ethnographic information on the musselers. The production process, modeled after both the timber and readymade clothing industries, was based on piecework by men who cut blanks and women who faced, sorted, and carded them. Labor issues were largely responsible for the industry's inability to compete successfully with the Japanese product by 1919 , while the raw material resulted in a high proportion of unsalable buttons. These two factors combined to kill the shell button industry by 1950 .

But musseling in the Mississippi Valley watershed did not die with the freshwater pearl button industry. Those who dealt the death blow, the Japanese, found another use for those shells. Today, Mississippi watershed mussels are used in the Japanese cultured pearl industry and the infant United States cultured pearl industry. Thousands of American men and women have made a living musseling for this Japanese industry since 1950. Interviews with several people give the flavor of this little-known livelihood and portend an end to a century of commercial musseling as the Japanese round pearl is replaced by the cultured baroque pearl, produced in the Tennessee River, which does not begin with a shell pellet. One hundred and fifty years of Anglo-American commercial musseling began with natural pearls and it may end with the cultured pearl in the next two decades. 


\section{REFERENCES}

ALCOA NEWS (AN)

1936 Buttons from River Beds. ALCOA News, 29 June:3.

\section{AMERICAN Fisheries Society}

1911 Transactions of the American Fisheries Society Meeting, September 27-29, 1910, at New York City, No. 40. American Fisheries Society, Washington, D.C.

\section{AMERICAN MACHINIST}

1915 Making Buttons from Various Kinds of Shells. American Machinist, 9 December:1029-1031.

Anderson County News [Clinton, Tennessee] (ACN)

1909 Pearl Hunting. Anderson County News, 14 August:3.

1912a Local News. Anderson County News, 30 March:3.

1912b Local News. Anderson County News, 6 April:3.

1912c Local News. Anderson County News, 22 June:3.

1912d Local News. Anderson County News, 24 August:3.

1913a Ad. Anderson County News, 23 August:2.

1913b Jolly Camping Party. Anderson County News, 23 August:3.

1913c Ad. Anderson County News, 30 August:2.

1920 Local Items. Anderson County News, 10 July:3.

1925 Local Items. Anderson County News, 20 June:3.

1935 Last Gate in Dam Is Closed. Anderson County News, 21 June:1.

ARPY, JIM

1965 Clamming Returns to the River. Times Democrat, 27 June:19A. Davenport, Iowa.

1969 Plastic Punches Out Pearl. Times Democrat, 23 February:10D. Davenport, Iowa.

1971 Button Button. . . Times Democrat, 28 June:11. Davenport, Iowa.

Bartenhagen, Mabel

[1976] Notes of Mabel Bartenhagen. Notes on file, Musser Public Library, Muscatine, Iowa.

\section{BLOOM, HERBERT}

1969 Economic Activities of the Jews of Amsterdam in the 17th and 18th Century. Kennikat Press, Port Washington, New York.

BOEPPLE, JoHN F.

1900 Story of Mr. Boepple (Letter to the Editor from Boepple). Muscatine Journal, 4 October:4. Muscatine, Iowa.

BranN, W. Paul

1947 Fresh-Water Mussel Shells. U.S. Fish and Wildlife Service Fishery Leaflet No. 246. U.S. Government Printing Office, Washington, D.C.

BURLington HaWkeye [Iowa]

1901 To Finish Buttons. Burlington Hawkeye, 8 February:6.
Burrell, Howard A.

1909 Burrell's History of Washington County, Iowa, Vol. 1. S. J. Clarke, Chicago, Illinois.

Button Industry Clipping File (BICF)

1895 Title unknown. Muscatine Journal, 11 September. Button Industry Clipping File, Musser Public Library, Muscatine, Iowa.

[1899] How Pearl Buttons Are Manufactured in Japan. Button Industry Clipping File, Musser Public Library, Muscatine, Iowa.

1904 Interesting Facts of the Mississippi and the Pioneer of the Button Business. Button Industry Clipping File, Musser Public Library, Muscatine, Iowa.

[1910] American Pearl Button Company. Evening Journal. Button Industry Clipping File, Musser Public Library, Muscatine, Iowa.

1938- Sales Receipts to Joe Keithley. Button Industry

1939 Clipping File, Musser Public Library, Muscatine, Iowa.

1953 Hagermann Is Dean of Pearl Button Industry. Des Moines Register, 5 April. Button Industry Clipping File, Musser Public Library, Muscatine, Iowa.

1974 Lansing's Button Business from Clams to Computers. Des Moines Sunday Register, 19 May. Button Industry Clipping File, Musser Public Library, Muscatine, Iowa.

Button Workers' BuLletin (BWB)

1911 The Grievances of the Button Workers of Muscatine, Iowa. Button Workers' Bulletin, 10 October. Muscatine, lowa.

1912 Button Workers' Bulletin 2(1). Muscatine, Iowa.

\section{Button Workers' Protective Union}

1911 What the Button Workers Want. Flyer on file, Musser Public Library, Muscatine, Iowa.

CaHN, A. R.

1949 Pearl Culture in Japan. General Headquarters Supreme Commander for the Allied Powers, Natural Resources Section Report No. 122. Tokyo.

\section{Carlander, Harriet}

1954 A History of Fish and Fishing in the Upper Mississippi River. Upper Mississippi River Conservation Commission, Davenport, Iowa.

Chansler, Walter S.

1921 Water-Craft of the Lower Wabash. Fur News and Outdoor World 34:10-15.

\section{City DiRectory of KnoxviLle}

1906 City Directory of Knoxville. G. M. Connelly, Knoxville, Tennessee.

1911- City Directory of Knoxville. Knoxville Directory 1917 Co., Knoxville, Tennessee.

Claassen, Cheryl (COMPiler)

1986a Taped Interview with Butch Ballinger, 14 August. Tape on file with the author. 
1986b Taped Interview with Larry, 14 August. Tape on file with the author.

1986c Taped Interview with Jeff, 14 August. Tape on file with the author.

1987a Taped Interview with Dan McFall, 31 September. Tape on file with the author.

1987b Taped Interview with W. L. Whitlock, 30 September. Tape on file with the author.

1987c Taped Interview with Daryl, 30 September. Tape on file with the author.

1987d Taped Interview with Marty, 30 September. Tape on file with the author.

1987e Taped Interview with Charlie, 1 October. Tape on file with the author.

1987f Taped Interview with Toni, 1 October Tape on file with the author.

1987g Taped Interview with Marge and Lyle Flynt, 1 October. Tape on file with the author.

1987h Taped Interview with Peggy Chadwick, 2, 3 October. Tape on file with the author.

1991 Gender, Shellfishing, and the Shell Mound Archaic. In Engendering Archaeology, edited by Joan Gero and Margaret Conkey, pp. 276-300. Basil Blackwell, Oxford.

Clark, Clarence F.

1971 Management of Naiad Populations in Ohio. In Rare and Endangered Mollusks (Naiads) of the U.S., pp. 26-33. U.S. Department of Interior, Fish and Wildlife Service, Washington, D.C.

Clark, Florence L.

1951 Clamming Returns to Upper Mississippi River. Cedar Rapids Gazette, 28 October:2. Cedar Rapids, Iowa.

Clark, H. Walton, and Charles B. Wilson

1912 The Mussel Fauna of the Maumee River. U.S. Bureau of Fisheries Document 757. Washington, D.C.

COKER, Robert F.

1912 Mussel Resources of the Holston and Clinch Rivers of Eastern Tennessee. U.S. Bureau of Fisheries Document 765. Washington, D.C.

1914 The Protection of Freshwater Mussels. U.S. Bureau of Fisheries Document 793. Washington, D.C.

1915 Mussel Resources of the Tensas River of Louisiana. U.S. Bureau of Fisheries Economic Circular 14 (April). Washington, D.C.

1919 Fresh-water Mussels and Mussel Industries of the United States. Bulletin of the U.S. Bureau of Fisheries for 1917-1918. Washington, D.C.

1930 Studies of Common Fishes of the Mississippi River at Keokuk. U.S. Bureau of Fisheries Document 1072. Washington, D.C.

COKer, Robert, AND John Southall

1915 Mussel Resources in Tributaries of the Upper Missouri River. U.S. Bureau of Fisheries Document 812. Washington, D.C.
Connell, Doug

1987 Old Buttons Unearthed. La Crosse Tribune, 22 June:6. LaCrosse, Wisconsin.

Crego, Phillip

1979 From Shell to Shirt. Manuscript on file, Archaeology Lab, Arkansas State University, State University, Arkansas.

DANGlade, ERNEST

1914 The Mussel Resources of the Illinois River. U.S. Bureau of Fisheries Document 804. Washington, D.C.

1922 Kentucky River and Its Mussel Resources. U.S. Bureau of Fisheries Document 934. Washington, D.C.

Davison's Knit Goods Trade Catalogue (DKGTC)

1931 Davison's Knit Goods Trade Catalogue (September). Davison, New York.

1948 Davison's Knit Goods Trade Catalogue (October). Davison, New York.

\section{DENTON, Howard}

1977 A Forgotten Industry. The Madison Courier, 8 February: 1 . Madison, Indiana.

DONOVAN, Timothy

[1979] The Unionid Mussels of Ft. Gibson Reservoir, Oklahoma Population Estimates, and the Impact of Commercial Harvesting. Manuscript on file, Oklahoma Department of Wildlife Conservation, Oklahoma City.

Drake, Lillian T.

1983 The Wabash River Pearl. Vincennes Sun-Commercial, 9 January:2,3,5. Vincennes, Indiana.

ELDRIDGE, JOHN

1914 The Mussel Fishery of the Fox River. U.S. Bureau of Fisheries Document 804. Washington, D.C.

Ellis, Leslie

1976 River Treasure: Those Who Search for Wabash Pearls Most Likely Take Them to G. H. Palmer. Louisville Courier Journal, 1 March:1, 14. Louisville, Kentucky.

ENGLEHART, GoRDON

1978 A Change of Culture. Louisville Courier Journal, 23 July:12. Louisville, Kentucky.

FARREL-Beck, JANE A., AND

RebecCa HatField MeinTs

1983 The Role of Technology in the Fresh-Water Pearl Button Industry of Muscatine, Iowa, 1891-1910. Annals of Iowa 47:3-18.

FULCHER, ROBERT

1982 Taped Interview with J. C. Bruce, 13 November. Tape on file, Nathan Bedford Forrest Museum, Camden, Tennessee. 
GOODRICH, JOHN

1946 Willington Industries. Manuscript on file, Button Industry Clipping File, Musser Public Library, Muscatine, Iowa.

GUNTER, JACK

1973 Kentucky Lake: Losing Its Mussel. Nashville Banner, 17 August:45. Nashville, Tennessee.

HAEFNER, MARIE

1932 Argonauts of the Mississippi. The Palimpsest, December:473-486. Iowa City, Iowa.

HaRT, NANCY

1981 The Pearl Button Company: The Working Process of Button Manufacturing. Indiana History Bulletin 58: 121-125.

Hawkeye Pearl Button Company

[1911] Pearls of the Mississippi. Booklet on file, Musser Public Library, Muscatine, Iowa.

HAYES, RiCK

1977 Mussel Fishing Is "Industry" for Vincennes. Vincennes Sun-Commercial, 27 July:29. Vincennes, Indiana.

HICKOK, GARY

1962 Muscatine Dreads Low Button Duty. Des Moines Sunday Register, 1 April:6-L. Des Moines, Iowa.

Hiller, ERNEST TheOdore

1939 Houseboat and River Bottoms People: A Study of 683 Households in Sample Localities Adjacent to the Ohio and Mississippi Rivers. Illinois Studies in the Social Sciences 24(1). University of Illinois Press, Urbana.

HiNKS, STEPHEN

1988 A Structural and Functional Analysis of EighteenthCentury Buttons. Unpublished M.A. thesis, Department of Anthropology, College of William and Mary, Williamsburg, Virginia.

Hughes, Elizabeth, and Marion Lester

1991 The Big Book of Buttons. Second printing. Boyerstown Publishing, Boyerstown, Pennsylvania.

Hughes, Frances

1962 An Old Shell Game. Louisville Courier Journal, 10 June:33, 36. Louisville, Kentucky.

Hull, Clifton

1981 River Pearls. Rural Arkansas, April:8-9. Little Rock, Arkansas.

HURD, Frances Schreurs

1966 The Pearl Button Industry of Muscatine, Iowa. Annals of Iowa 38(6):401-411. Des Moines, Iowa.

INGRAM, PAUL

1975 Tales of Pearl City: Pearling a Shell of "Rush" Days. Valley Advance, 9 December:3-4. Vincennes, Indiana.
INTERSTATE COMMERCE COMMISSION (ICC)

1916a McKee and Bliven Button Company v. Illinois Central Railroad Company, Case No. 7994. Interstate Commerce Commission Reports 39:627. Washington, D.C.

1916b Henry Kath Company v. Chicago, Rock Island and Pacific Railway, Case No. 8,239. Interstate Commerce Commission Reports 39:613. Washington, D.C.

1918 Henry F. Kath Company v. Alabama, Tennessee \& Northern Railway, Case No. 8919. Interstate Commerce Commission Reports 47:42-44. Washington, D.C.

IoWA MAGAZINE

1919 Pennant Ad. lowa Magazine, June:39.

Isom, Billy G.

1969 The Mussel Resources of the Tennessee River. Malacologia 7(2-3):397-425.

\section{JACKSON, KEN}

1979 Shell-Fishing Threatened by Pollution of Lake. Tulsa World, 27 September:F-1. Tulsa, Oklahoma.

JONES, W. UNITE

1924 The Button Industry. Sir Isaac Pittman and Sons, London.

JoRgenSEN, S. E., AND R. W. SHARP

1971 Rare and Endangered Mollusks of the U.S. Proceedings of a Symposium on Rare and Endangered Mollusks. U.S. Department of the Interior, Fish and Wildlife Service, Bureau of Sport Fisheries and Wildlife, Region 3. Ft. Snelling, Minnesota.

Kelso, Margaret F.

1971 A Classification of Pearl and Shell Buttons. Boyertown Publishing, Boyertown, Pennsylvania.

Kidwell, Claudia, and Margaret Christman

1974 Suiting Everyone: The Democratization of Clothing in America. Smithsonian Institution Press, Washington, D.C.

KLein, Charles R.

1949 Klein Recalls Kid Fun at Old Button Factory. Madison Courier, 26 September:5. Madison, Indiana.

KNAUTh, OtTo

1969 The Iowa Clam's Contribution to the Lovely Japanese Pearl. Des Moines Sunday Register, 17 August:8. Des Moines, Iowa.

KRESGE

1913 Kresge Catalogue. S. S. Kresge, Detroit, Michigan.

KunZ, George F.

1898 The Fresh-Water Pearls and Pearl Fisheries of the United States. U.S. Fish Commission Bulletin 17: 373-426. Washington, D.C. 
LA CRosse Tribune [Wisconsin]

1912 Button Company Good Employer. La Crosse Tribune, 30 August:41.

LIFE AND LABOR (LL)

1911 Buttons-Pearl Buttons. Life and Labor, May:143145. Chicago, Illinois.

LONGSTRETH, O. D.

1906 The Pearl Button Industry in Iowa. Unfinished M.A. thesis, Department of Science, University of Iowa. Manuscript on file, State Historical Society of Iowa, Iowa City.

LUND, JENS

1983 Fishing as a Folk Occupation in the Lower Ohio Valley. Ph.D. dissertation, Department of Folklore, University of Indiana, Bloomington. University Microfilms, Ann Arbor.

LUSCOMB, SALLY

1967 The Collector's Encyclopedia of Buttons. Crown, New York.

MACGregor, Arthur

1985 Bone, Antler, Ivory, \& Horn: The Technology of Skeletal Materials Since the Roman Period. Croom Helm, London.

MadsON, JoHN

1985 Mississippi Shell Game. Audubon 87(2):47-69.

MaGic Valley [Camden, Tennessee]

1986 Big Sandy Area to Get Major Pearl Farming Operation. Magic Valley Shopper's News, 5 March:1.

McCay, Margie

1982 Buttons Still in Muscatine Even Though Clams Gone. Muscatine Journal, 13 July:1, 15. Muscatine, Iowa.

McCormack, GeOrge

1960 Reviving Pearl City. Indianapolis Star Magazine, 16 October:48-52. Indianapolis, Indiana.

MCKeE, JAmes, AND William BLIVEN

1907- Correspondence between James McKee and William

1912 Bliven. Documents on file, McKee Button Company, Muscatine, Iowa.

Meek, S. E., and H. Walton Clark

1912 The Mussels of the Big Buffalo Fork of White River, Arkansas. U.S. Bureau of Fisheries Document 759. Washington, D.C.

Memphis City Directory

1906 Memphis City Directory. R. L Polk, Memphis, Tennessee.

MeRCY, A. A.

[1959] Veteran Pearl Buyer Makes Best Purchase Here. Vincennes Times. Pearl City, Pearl Industry vertical file, Knox County Library, Vincennes, Indiana.
Miller, GeORGe H.

1967 Old Button Factory Bought Muckets at \$30 Ton. Madison Weekly Herald, 11 February:12. Madison, Indiana.

MONTGOMERY WARD

1895 Montgomery Ward Catalogue. Montgomery Ward, Chicago, Illinois.

\section{Muscatine City Directory}

1892- Muscatine City Directory. Journal Office, Musca1893 tine, Iowa

1897- Muscatine City Directory. Tribune Job Office, Mus1900 catine, Iowa.

1908- Muscatine City Directory. R. L Polk, Davenport, 1921 Iowa.

\section{Muscatine County District Court}

[Muscatine, Iowa] (MCDC)

1898a John J. Meyer v. Boepple Button Company, 5 May 1898, Muscatine County District Court Case No. 6461. Muscatine, Iowa.

1898b Louis Kopp v. Boepple Button Company, 28 January 1898, Muscatine County District Court Case No. 6559. Muscatine, Iowa.

1899a W. R. Evens v. Standard Pearl Button Company, 6 March 1899, Muscatine County District Court Case No. 6842. Muscatine, Iowa.

1899b J. H. Bryant v. Standard Button Company, 10 March 1899, Muscatine County District Court Case No. 6849. Muscatine, Iowa.

1901 D. J. Lenehan v. Leo H. Hirsch and Company, 5 February 1901, Muscatine County District Court Case No. 7255. Muscatine, Iowa.

1902a Keystone Pearl Button Company v. D. J. Lenehan, no date, Muscatine County District Court Case No. 7366. Muscatine, Iowa.

1902b F. E. Smith v. Keystone Pearl Button Company, no date, Muscatine County District Court Case No. 7573. Muscatine, Iowa.

1902c Keystone Pearl Button Company v. Fred Boston, 16 May 1902, Muscatine County District Court Case No. 7581. Muscatine, lowa.

1902d Keystone Pearl Button Company v. D. J. Lenehan, no date, Muscatine County District Court Case No. 7602. Muscatine, Iowa.

1902e Keystone Pearl Button Company v. D. J. Lenehan, no date, Muscatine County District Court Case No. 7664. Muscatine, Iowa.

1903a German American Savings Bank v. Keystone Pearl Button Company, 4 December 1903, Muscatine County District Court Case No. 7671. Muscatine, Iowa.

1903b Royal Pearl Button Company v. Keystone Pearl Button Company, 13 January 1903, Muscatine County District Court Case No. 7702. Muscatine, Iowa. 
1903c John Loog v. Royal Pearl Button Company, 2 June 1903, Muscatine County District Court Case No. 7797. Muscatine, Iowa.

1903d J. F. Boepple v. William Huttig, 10 December 1903 , Muscatine County District Court Case No. 7834. Muscatine, lowa.

1904 Bishop and Hagerman v. Valley Button Company, 27 May 1904, Muscatine County District Court Case No. 8030. Muscatine, Iowa.

1905 Hirsch, Leo H., v. Fred C. Vetter, 5 July 1906, Muscatine County District Court Case No. 8196. Muscatine, lowa.

1906a Barry Manufacturing Company v. Wabash Pearl Specialty Company, 23 May 1906, Muscatine County District Court Case No. 8546. Muscatine, Iowa.

1906 b G. J. and C. Hampe v. Teichmiller Bros., 28 December 1906, Muscatine County District Court Case No. 8628. Muscatine, Iowa.

1907 Huttig-McDermid Pearl Button Company v. Soaper and Barrett, 15 October 1907, Muscatine County District Court Case No. 8935. Muscatine, Iowa.

1908a McKee and Bliven v. A. P. Wallace, 9 April 1908, Muscatine County District Court Case No. 8989. Muscatine, Iowa.

1908b Hirsch, Leo H., Company v. A. P. Wallace, 28 December 1908, Muscatine County District Court Case No. 9094. Muscatine, Iowa.

1908c Marguereta Markee v. Leo Hirsch and Company, 8 September 1908, Muscatine County District Court Case No. 9564. Muscatine, Iowa.

1912 W. B. Phelps v. Empire Button Company, 18 February 1912, Muscatine County District Court Case No. 10205. Muscatine, Iowa.

1915a Henry Tober v. McKee and Bliven Company, 1 November 1915, Muscatine County District Court Case No. 10052. Muscatine, Iowa.

1915b Kate Sell v. McKee and Bliven Company, 1 November 1915, Muscatine County District Court Case No. 10064. Muscatine, Iowa.

1915c Rose Phillips v. McKee and Bliven Company, 1 November 1915, Muscatine County District Court Case No. 10065. Muscatine, Iowa.

1915d Minnie Pantel v. McKee and Bliven Company, 1 November 1915, Muscatine County District Court Case No. 10066. Muscatine, Iowa.

1915e Mabel Gunzenhauser v. McKee and Bliven Company, 1 November 1915, Muscatine County District Court Case No. 10067. Muscatine, Iowa.

1916 Empire City Pearl Button Company v. Chicago, Milwaukee, St. Paul Railroad, 11 March 1916, Muscatine County District Court Case No. 10886. Muscatine, lowa.

1918 Clover Button Company v. George Birrell, Inc., 1 July 1918, Muscatine County District Court Case No. 11979. Muscatine, Iowa.
MusCatine Journal [Iowa] (MJ)

1900 Stole Pearl Buttons. Muscatine Journal, 6 January: Sec. 2-1.

1907 Largest Button Plant in the World. Muscatine Journal, 19 December:11.

1915 Weber Button Company Signalizes Most Prosperous Year by Expansion. Muscatine Journal, 11 December:Sec. 5-8.

1922 Button Production-New Protective Tariff Hailed. Muscatine Journal, 30 December: 13.

1928a Button Factories Are Muscatine's Greatest Commercial Asset. Muscatine Journal, 31 December:8-10.

1928b Plant of the Automatic Factory (photo caption). Muscatine Journal, 31 December:9.

192911 Million Gross Buttons Made Here in 1927. Muscatine Journal, 21 January:1.

1938a Heads of Hawkeye Firm Have Long Record of Association in Industry. Muscatine Journal, 30 December:Year End Edition, Muscatine Industry section:2.

1938b Automatic Button Company, One of Pioneers in Field, Is Observing Its 40th Anniversary This Year. Muscatine Journal, 30 December:Year End Edition, Muscatine Industry section:5.

1938c Procuring and Selling of Fresh Water Pearls Proved Profitable Industry Here for Many Years. Muscatine Journal, 23 July:9.

1938d Manufacturers Join in Promotional Drive. Muscatine Journal, 30 December:Year End Edition, Muscatine Industry section:2.

1948a Pearl Buttons Processed on Machinery Made by Barry Company of Muscatine Used on Garments in Many Lands. Muscatine Journal, 5 February:11.

1948b Clam Shells from the Bed of Mississippi Feed Muscatine's Most Important Industry. Muscatine Journal, 18 March:17.

1948c “Steam Men”' Were Skeptical as Iowa Pearl Became First Button Firm to Use Electricity. Muscatine Journal, 8 April:6.

1948d McKee Button Co. After Modest Start as Small Cutting Plant, Now Operates World's Largest Button Factory Here. Muscatine Journal, 10 June:6.

1948e Former Muscatine Man Is Grower of Flawless Pearls. Muscatine Journal, 26 June:5.

1948f Butterfly Drama Enacted at Perkins Novelty Works as Shells Bloom into Rainbow-Hued Buckles and Brooches. Muscatine Journal, 29 July:15.

1955 Kin of Pioneer Founder of Button Industry Guest Here. Muscatine Journal, 9 June:18.

1959 Photo, Using Diamond Saw. Muscatine Journal, 30 December:17.

1962 Muscatine Pearl Works Builds New Plant. Muscatine Journal, 3 May:1.

1967 Automatic Button Co. in Court Receivership. Muscatine Journal, 31 October:2.

1976a Program Given About Buttons. Muscatine Journal, 15 March:2. 
1976b Button Machine Innovator Francis Tompkins Retires. Muscatine Journal, 27 July:20.

MYER, W. E.

1914 Pearl Fisheries of Tennessee. Transactions of the Tennessee Academy of Sciences 2:19-25.

Nichols, William

1923 Romance of the Pearl Button Industry. Burlington Hawkeye, 6 May:Part 2(1). Burlington, Iowa.

OESCH, Ronald D.

1984 Missouri Naiades. Missouri Department of Conservation, Columbia, Missouri.

O'Hara, Mike

1981 Mr. Boepple and His Buttons. The Iowan, Fall:4651.

OHIO RIVER Basin COMPREHENSIVE SURVEY

1960 Ohio River Basin Comprehensive Survey, Vol. 8, Appendix G. U.S. Department of the Interior, U.S. Fish and Wildlife Service. Washington, D.C.

OHNEMUS, JACK

1967 Musselman Proposes River Be Closed for Seven Years. Vincennes Sun-Commercial, 7 May:10.

Oral History TAPE (OHT)

1971 Interview with Jerome C. Bishop: Pearl Button History. Oral History Tape 10. Audio Visual Department, Musser Public Library, Muscatine, Iowa.

1973 Weber Family and Their Button Company. Oral History Tape 25. Audio Visual Department, Musser Public Library, Muscatine, Iowa.

Peterson, William J.

1952 The Story of Iowa, Vol. 4. Lewis Historical Publishing, New York.

Proske, BoB

1982 Pearl City. Evansville Courier, 16 April:3. Evansville, Indiana.

Prosser, Richard B.

1970 Birmingham Inventors and Inventions, Being a Contribution to the Industrial History of Birmingham. S. R. Publishers, London.

RANKIN, TOM (COMPILER)

1982a Taped Interview with T. J. Whitfield, 9 September. Tape on file, Nathan Bedford Forrest Folklife Museum, Camden, Tennessee.

1982b Taped Interview with M. F. Matlock, 8 October. Tape on file, Nathan Bedford Forrest Folklife Museum, Camden, Tennessee.

1982c Taped Interview with John Latendresse, 28 December. Tape on file, Nathan Bedford Forrest Folklife Museum, Camden, Tennessee.

RHOADES, RENDALL

1951 Clam Shells and Buttons. Ohio Conservation Bulletin, June:14-15.
RichMaN, I.

1911 The History of Muscatine County, Iowa, Vol 1. S. J. Clarke Publishing, Chicago, Illinois.

Riggs, BRETT

1993 Material Dimensions of Removal Period Cherokee Households in Southwestern North Carolina. Ph.D. dissertation, Department of Anthropology, University of Tennessee, Knoxville. University Microfilms, Ann Arbor.

Rousmaniere, KaTE

1982 The Muscatine Button Workers' Strike of 1911-12. Annuals of Iowa 46:243-262.

RUSSELL, WALTER

1966 Umlandt, 78, Perfects Efficient Button Making Machine. Muscatine Journal, 22 January:1. Muscatine, Iowa.

ScarPino, Phillip

1985 Great River: An Environmental History of the Upper Mississippi, 1890-1950. University of Missouri Press, Columbia.

SCHEER, JAMES F.

1948 Pearls-to-Order by Bostwick. The Coronet, July:6770. Chicago

SCIENTIFIC AmERICAN (SA)

1893 The Pearl Button Industry. Scientific American, 29 April:260-261.

SCUdDER, MARVYN

1926 Manual of Extinct or Obsolete Companies, Vol 1. Marvyn Scudder Manual of Extinct or Obsolete Companies, New York.

SEARS

1895- Sears Catalogues. Sears, Roebuck, Chicago, Illi1939 nois.

SEBRING, EDWARD

1985 Documentary on Mussel Fishing Debuts. Vincennes Sun-Commercial, 14 October:1, 5. Vincennes, Indiana.

SHIRA, Austin

1913 The Mussel Fisheries of Caddo Lake and the Cypress and Sulphur Rivers of Texas and Louisiana. Bureau of Fisheries Economic Circular 6. Washington, D.C.

SMITH, Hugh

1898 The Mussel Fishery and Pearl-Button Industry of the Mississippi River. Bulletin of the U.S. Fisheries Commission 18. Washington, D.C

SNODDY, DiANE

1966 Tennessee River Business Declines. Nashville Banner, 9 June:16. Nashville, Tennessee. 
South, STANLeY

1964 Analysis of the Buttons from Brunswick Town and Fort Fisher. Florida Anthropologist 17(2):113-133.

\section{Stansbery, David}

1971 Comments. In Rare and Endangered Mollusks of the U.S., edited by S. E. Jorgenson and R. W. Sharp, p. 72. U.S. Department of the Interior, Fish and Wildlife Service, Bureau of Sport Fisheries and Wildlife. Washington, D.C.

STANWOOD, EDWARD

1903 American Tariff Controversies in the Nineteenth Century, Vol. 2. Russell and Russell, New York.

Stockard, S. W.

1904 History of Lawrence, Jackson, Independence and Stone Counties, Arkansas. Arkansas Democrat, Little Rock.

STRINGHAM, EMERSON

1917 Fish Laws of Mississippi River States, Appendix 4. Report of the U.S. Commissioner of Fisheries for 1916. Washington, D.C.

TAYLOR, RALPH W.

1980 A Survey of the Freshwater Mussels of the Ohio River from Greenup Locks and Dam to Pittsburgh, Pennsylvania. Report prepared by Ralph W. Taylor. Submitted to U.S. Army Corps of Engineers, Huntington District, Huntington, West Virginia.

TownSEND, C. H.

1901 Statistics of the Fisheries of the Mississippi River and Tributaries. U.S. Commission of Fish and Fisheries, Committee Report. Washington, D.C.

U.S. Bureau of the Census (USBC)

1923 Census of Manufactures, Vol. 2. U.S. Government Printing Office, Washington, D.C.

1925 Census of Manufactures, Vol. 2. U.S. Government Printing Office, Washington, D.C.

1927 Census of Manufactures, Vol. 2. U.S. Government Printing Office, Washington, D.C.

1929 Census of Manufactures, Vol. 2. U.S. Government Printing Office, Washington, D.C.

1931 Census of Manufactures, Vol. 2. U.S. Government Printing Office, Washington, D.C.

1935 Census of Manufactures, Vol. 2. U.S. Government Printing Office, Washington, D.C.

1937 Census of Manufactures, Vol. 2. U.S. Government Printing Office, Washington, D.C.

1947 Census of Manufactures, Vol. 2. U.S. Government Printing Office, Washington, D.C.

1954 Census of Manufactures, Vol. 2. U.S. Government Printing Office, Washington, D.C.

1958 Census of Manufactures, Vol. 2. U.S. Government Printing Office, Washington, D.C.

1963 Census of Manufactures, Vol. 2. U.S. Government Printing Office, Washington, D.C.

\section{U.S. DEPARTMENT OF THE INTERIOR}

1957 Annual Summary for 1957. U.S. Fish and Wildlife Service, Commercial Fisheries Statistics, No. 1756 16. Washington, D.C.

U.S. DEPARTMENT OF LABOR

1947 The Pearl Button Industry in Puerto Rico. U.S. Department of Labor, Wage, and Hour and Public Contracts Office Report, June. Washington, D.C.

\section{U.S. HOUSE OF REPRESENTATIVES (USHR)}

1897 Tariff Hearings before the Committee on Ways and Means, Vol 2. U.S. House of Representatives, Washington, D.C.

1919 Pearl Buttons Hearings before a Special Subcommittee of the Committee on Ways and Means, June 23 and 24. U.S. House of Representatives, Washington, D.C.

\section{U.S. SEnate (USS)}

1919 Pearl Buttons Hearings before the Committee on Finance, 15-16 December. U.S. Senate, Washington, D.C.

VINCENNES SUN-COMmERCIAL [Indiana] (VSC)

1911 Another Fine Pearl Found. Vincennes Sun-Commercial, 22 June:1.

1956 Mussel Diggin' Still Goes on Here, But Prices Are Down and a Good Shell Is Hard to Come By. Vincennes Sun-Commercial. Pearl City, Pearl Industry Clipping File, Knox County Public Library, Vincennes, Indiana.

1957 Vincennes Vignette. Vincennes Sun-Commercial, 10 May:12.

1966 White River Gives Up "Gold" Treasure. Vincennes Sun-Commercial, 27 July:3.

Walker, Malcolm T.

1971 Riverpeople of Clayton: Poor Whites in a Community in Southern Illinois. Southern Illinois Studies 6. Southern Illinois University Museum, Carbondale.

WARD, Fred

1984 The Pearl. National Geographic, August:193-222.

WASHINGTON EVENING JouRNAL [lowa] (WEJ)

1936 American Pearl Button Company. Washington Evening Journal, 29 June:58. Washington, Iowa.

1953 Buttons Mean Jobs to Local People. Washington Evening Journal, 23 January:1, 6. Washington, Iowa.

Wells, Horace V., JR.

1973 Freshwater Pearl, Mussel Industry Once Thrived Here. Courier-News, 5 April:1-2. Clinton, Tennessee.

WIDNEY, STAN

1962 Historically Speaking. Button Industry Clipping File, Musser Public Library, Muscatine, Iowa. 
Williams, JoHN C.

1969 Mussel Fishery Investigations, Tennessee, Ohio and Green Rivers: Final Report. Report [Project No. 4-19-R] Prepared by Murray State University Biological Station, Murray, Kentucky. Submitted to Kentucky Department of Fish and Wildlife Resources, Frankfort.

\section{WiLliams, Winston}

1962 Twenty Fathoms Down for Mother-of-Pearl. $\mathrm{Na}$ tional Geographic, April:513-529.

\section{Willis, Douglas A.}

1928 Story of Button Industry in Pre-Muscatine Era and Early Days Here Written by Willis. Muscatine Journal, 31 December:9.

Wilson, Charles B., and H. Walton Clark

1914 The Mussels of the Cumberland River and Its Tributaries. U.S. Bureau of Fisheries Document 781. Washington, D.C.
Wilson, Charles B., and ERnest Danglade

1913 The Mussel Fauna of Central and Northern Minnesota. U.S. Bureau of Fisheries Report 803. Washington, D.C.

\section{Wisconsin Pearl Button Company}

[1913] Made in America: Descriptive Story of a Purely American Industry. Special Collections, Ephemeral File, Subject Industries-Wisconsin Pearl Button Company. La Crosse Public Library, La Crosse, Wisconsin.

\section{WOOLLEY, EDWARD MOTT}

1914 Buttons; A Romance of American Industry. McClure's, February:113-120.

ZEITNER, JUNE

1968 Native Freshwater Pearls. Lapidary Journal, April: 146-154. 